\title{
Front Matter: Volume 7729
}

, "Front Matter: Volume 7729," Proc. SPIE 7729, Scanning Microscopy 2010, 772901 (22 June 2010); doi: 10.1117/12.869740

SPIE. Event: Scanning Microscopy 2010, 2010, Monterey, California, United States 


\section{PROCEEDINGS OF SPIE}

\section{Scanning Microscopy 2010}

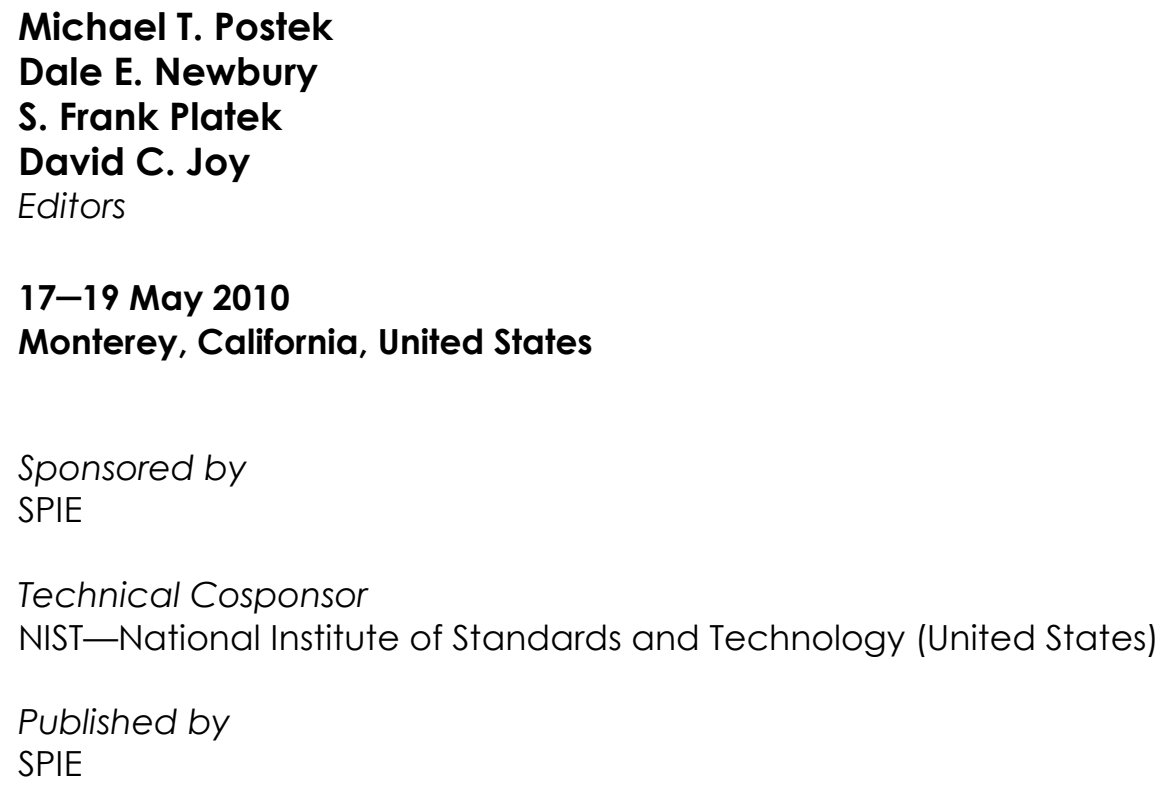


The papers included in this volume were part of the technical conference cited on the cover and title page. Papers were selected and subject to review by the editors and conference program committee. Some conference presentations may not be available for publication. The papers published in these proceedings reflect the work and thoughts of the authors and are published herein as submitted. The publisher is not responsible for the validity of the information or for any outcomes resulting from reliance thereon.

Please use the following format to cite material from this book:

Author(s), "Title of Paper," in Scanning Microscopy 2010, edited by Michael T. Postek,

Dale E. Newbury, S. Frank Platek, David C. Joy, Proceedings of SPIE Vol. 7729 (SPIE, Bellingham, WA, 2010) Article CID Number.

ISSN 0277-786X

ISBN 9780819482174

Published by

SPIE

P.O. Box 10, Bellingham, Washington 98227-0010 USA

Telephone +1 3606763290 (Pacific Time) · Fax +1 3606471445

SPIE.org

Copyright (C) 2010, Society of Photo-Optical Instrumentation Engineers

Copying of material in this book for internal or personal use, or for the internal or personal use of specific clients, beyond the fair use provisions granted by the U.S. Copyright Law is authorized by SPIE subject to payment of copying fees. The Transactional Reporting Service base fee for this volume is $\$ 18.00$ per article (or portion thereof), which should be paid directly to the Copyright Clearance Center (CCC), 222 Rosewood Drive, Danvers, MA 01923. Payment may also be made electronically through CCC Online at copyright.com. Other copying for republication, resale, advertising or promotion, or any form of systematic or multiple reproduction of any material in this book is prohibited except with permission in writing from the publisher. The CCC fee code is 0277-786X/10/\$18.00.

Printed in the United States of America.

Publication of record for individual papers is online in the SPIE Digital Library.

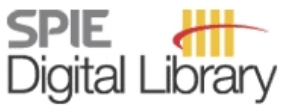

SPIEDigitalLibrary.org

Paper Numbering: Proceedings of SPIE follow an e-First publication model, with papers published first online and then in print and on CD-ROM. Papers are published as they are submitted and meet publication criteria. A unique, consistent, permanent citation identifier (CID) number is assigned to each article at the time of the first publication. Utilization of CIDs allows articles to be fully citable as soon they are published online, and connects the same identifier to all online, print, and electronic versions of the publication. SPIE uses a six-digit CID article numbering system in which:

- The first four digits correspond to the SPIE volume number.

- The last two digits indicate publication order within the volume using a Base 36 numbering system employing both numerals and letters. These two-number sets start with 00, 01, 02, 03, 04, $05,06,07,08,09,0 A, 0 B \ldots 0 Z$, followed by 10-1Z, 20-2Z, etc.

The CID number appears on each page of the manuscript. The complete citation is used on the first page, and an abbreviated version on subsequent pages. Numbers in the index correspond to the last two digits of the six-digit CID number. 


\section{Contents}

ix Conference Committee
xiii Introduction

\section{PLENARY SESSION}

772903 Peering into the secrets of food and agricultural co-products (Plenary Paper) [7729-201] D. Wood, T. Williams, G. Glenn, Z. Pan, W. Orts, T. McHugh, USDA Agricultural Research Service (United States)

772904 Electron microscopy of polymer-carbon nanotubes composites (Plenary Paper) [7729-202] E. M. Campo, H. Campanella, Instituto de Microelectrónica de Barcelona (Spain); Y. Y. Huang, Univ. of Cambridge (United Kingdom); K. Zinoviev, N. Torras, C. Tamargo, Instituto de Microelectrónica de Barcelona (Spain); D. Yates, L. Rotkina, Univ. of Pennsylvania (United States); J. Esteve, Instituto de Microelectrónica de Barcelona (Spain); E. M. Terentjev, Univ. of Cambridge (United Kingdom)

\section{ADVANCEMENTS IN PARTICLE BEAM MICROSCOPY I}

7729 OB Microstructure and texture analysis of advanced copper using electron backscattered diffraction and scanning transmission electron microscopy [7729-04] R. Galand, L. Clément, P. Waltz, STMicroelectronics (France); Y. Wouters, Science et Ingénierie des Matériaux et Procédés (France)

7729 OC Measuring the beam size of a focused ion beam (FIB) system [7729-05]

J. Orloff, FEl Co. (United States)

\section{ADVANCEMENTS IN PARTICLE BEAM MICROSCOPY II}

7729 OD NEW scanning electron microscope magnification calibration reference material (RM) 8820 [7729-06]

M. T. Postek, A. E. Vladár, W. Keery, National Institute of Standards and Technology (United States); M. Bishop, B. Bunday, J. Allgair, International SEMATECH (United States)

7729 OE A method for determining oceanic particle size distributions and particle composition using scanning electron microscopy coupled with energy dispersive spectroscopy [7729-07] H. Groundwater, M. S. Twardowski, WET Labs., Inc. (United States); H. M. Dierssen, Univ. of Connecticut (United States); A. Sciandre, Lab d'Océanologique de Villefranche, CNRS (France); S. A. Freeman, WET Labs., Inc. (United States)

7729 OF Pushing the envelope with SEM/SDD-EDS mapping: X-ray spectrum image mapping in 30 seconds or less, but what are the real limits? [7729-08]

D. Newbury, National Institute of Standards and Technology (United States) 
$77290 \mathrm{~J}$ Techniques for improving material fidelity and contrast consistency in secondary electron mode helium ion microscope (HIM) imaging [7729-12]

W. Thompson, L. Stern, D. Ferranti, C. Huynh, L. Scipioni, J. Notte, C. Sanford, Carl Zeiss SMT Inc. (United States)

\section{ADVANCEMENTS IN SCANNED PROBE MICROSCOPY}

7729 OL Traceable nanoscale length metrology using a metrological Scanning Probe Microscope [7729-13]

M. Lawn, J. Herrmann, C. H. Freund, J. R. Miles, M. Gray, National Measurement Institute of Australia (Australia); D. Shaddock, The Australian National Univ. (Australia); V. A. Coleman, A. K. Jämting, National Measurement Institute of Australia (Australia)

7729 OM Interlaboratory comparison of traceable atomic force microscope pitch measurements [7729-14]

R. Dixson, National Institute of Standards and Technology (United States); D. A. Chernoff, Advanced Surface Microscopy, Inc. (United States); S. Wang, A*STAR National Metrology Ctr. (Singapore); T. V. Vorburger, National Institute of Standards and Technology (United States); S. L. Tan, A*STAR National Metrology Ctr. (Singapore); N. G. Orji, J. Fu, National Institute of Standards and Technology (United States)

7729 ON Advanced 3D metrology atomic force microscope with crosstalk eliminated [7729-15] Y. Hua, C. Coggins, S. Park, Park Systems Inc. (United States); S. Park, Park Systems Corp. (Korea, Republic of)

772900 Low tip damage AFM technique development for nano structures characterization [7729-16] B. Liu, C. C. Wang, P.-F. Huang, Y. Uritsky, Applied Materials, Inc. (United States)

\section{ADVANCEMENTS IN PARTICLE BEAM MICROSCOPY III}

$77290 Q$ Physico-chemical characterization of engineered metal oxide nanoparticles: the critical role of microscopy [7729-20]

A. La Fontaine, V. A. Coleman, Å. K. Jämting, M. Lawn, J. Herrmann, J. R. Miles, National Measurement Institute of Australia (Australia)

7729 OR Complementing and adding to SEM performance with the addition of XRF, Raman, CL and PL spectroscopy and imaging [7729-67]

E. Leroy, S. Mamedov, E. Teboul, A. Whitley, D. Meyer, L. Casson, HORIBA Jobin Yvon Inc. (United States)

7729 OT Electron microscopy and cathodoluminescence in electrospun nanodimensional structures: challenges and opportunities [7729-69]

E. M. Campo, Ctr. Nacional de Microelectrónica (Spain) and Lehigh Univ. (United States); A. Meléndez, K. Morales, Univ. de Puerto Rico en Humacao (United States); J. Poplawsky, Lehigh Univ. (United States); J. J. Santiago-Avilés, Univ. of Pennsylvania (United States);

I. Ramos, Univ. de Puerto Rico en Humacao (United States) 
7729 OV Modeling of charging effects in scanning ion microscopes [7729-24]

K. Ohya, T. Yamanaka, D. Takami, K. Inai, Univ. of Tokushima (Japan)

7729 OW Comprehensive simulation of SEM images taking into account local and global electromagnetic fields [7729-25]

S. Babin, S. S. Borisov, Abeam Technologies (United States); H. Ito, Hitachi High-Technologies Corp. (Japan); A. Ivanchikov, D. Matison, V. Militsin, Abeam Technologies (United States); M. Suzuki, Hitachi High-Technologies Corp. (Japan)

7729 0X A novel Monte Carlo simulation code for linewidth measurement in critical dimension scanning electron microscopy [7729-26]

A. Koschik, M. Ciappa, S. Holzer, ETH Zürich (Switzerland); M. Dapor, FBK-IRST (Italy) and Univ. degli Studi di Trento (Italy); W. Fichtner, ETH Zürich (Switzerland)

$77290 Z$ Advances in modeling of scanning charged-particle-microscopy images [7729-29] P. Cizmar, A. E. Vladár, M. T. Postek, National Institute of Standards and Technology (United States)

772910 Optimizing the detector configuration for SEM topographic contrast by using a Monte Carlo simulation [7729-30]

M. Suzuki, Hitachi High-Technologies, Corp. (Japan); S. Borisov, S. Babin, Abeam

Technologies, Inc. (United States); H. Ito, Hitachi High-Technologies, Corp. (Japan)

772911 A feature-based approach for processing nanoscale images [7729-31]

G. Roughton, lona College (United States); A. S. Varde, S. Robila, Montclair State Univ.

(United States); J. Liang, Worcester Polytechnic Institute (United States)

\section{FORENSIC MICROSCOPY: APPLICATIONS, ANALYSES AND RESEARCH}

772913 Is this charred material from a VHS video cassette? [7729-34]

T. Fruchtenicht, El Cajon Police Dept. (United States); R. D. Blackledge, Forensic Chemist Consultant (United States); T. R. Williams, Army Fleet Support (United States)

772914 Dental materials as an aid for victim identification: examination of calcined remains by SEM/EDS [7729-35]

M. A. Bush, P. J. Bush, SUNY at Buffalo School of Dental Medicine (United States)

772915 Scanning methods applied to bitemark analysis [7729-36]

P. J. Bush, M. A. Bush, SUNY at Buffalo School of Dental Medicine (United States)

772916 The influence of surface chemistry on GSR particles: using XPS to complement SEM/EDS analytical techniques (Invited Paper) [7729-66]

A. J. Schwoeble, B. R. Strohmeier, J. D. Piasecki, RJ Lee Group, Inc. (United States)

772917 Investigation of gunshot residue patterns using milli-XRF-techniques: first experiences in casework [7729-37]

R. Schumacher, M. Barth, D. Neimke, L. Niewöhner, Bundeskriminalamt (Germany) 
772919 GSR particles and their evidential value [7729-39]

M. Kotrlý, I. Turková, Institute of Criminalistics Prague (Czech Republic)

7729 1B The Bayesian approach to reporting GSR analysis results: some first-hand experiences [7729-41]

S. Charles, B. Nys, Nationaal Instituut voor Criminalistiek en Criminologie (Belgium)

7729 1C Optimal compression and binarization of signature profiles for automated bullet identification systems [7729-42]

W. Chu, J. Song, T. Vorburger, R. Thompson, T. Renegar, R. Silver, National Institute of Standards and Technology (United States)

7729 1D Topography measurements for correlations of standard cartridge cases [7729-43] T. V. Vorburger, J. Song, W. Chu, T. B. Renegar, A. Zheng, J. Yen, R. M. Thompson, R. Silver, National Institute of Standards and Technology (United States); B. Bachrach, Intelligent Automation, Inc. (United States); M. Ols, Bureau of Alcohol, Tobacco, Firearms, and Explosives (United States)

\section{ADVANCEMENTS IN OPTICAL MICROSCOPY I}

7729 1G Transmission-type angle deviation microscope with NA=0.65 for 3D measurement [7729-46] M.-H. Chiu, C.-F. Lai, C.-T. Tan, Y.-Z. Lin, National Formosa Univ. (Taiwan)

7729 1H Resolution improvement in coherent diffractive imaging (ptychography) [7729-47] T. B. Edo, F. Zhang, J. M. Rodenburg, The Univ. of Sheffield (United Kingdom)

$772911 \quad$ A new method of high resolution, quantitative phase scanning microscopy [7729-48] A. M. Maiden, The Univ. of Sheffield (United Kingdom) and Phase Focus Ltd. (United Kingdom); J. M. Rodenburg, The Univ. of Sheffield (United Kingdom); M. J. Humphry, Phase Focus Ltd. (United Kingdom)

7729 IK Dielectric slot tip for scanning near-field microwave microscope [7729-50] P. Leidenberger, C. Hafner, ETH Zürich (Switzerland)

7729 1L Performance of a combined chromatic confocal microscope with thin film reflectometer [7729-51]

F. Hirth, T. C. Buck, N. Steinhausen, A. W. Koch, Technische Univ. München (Germany)

$77291 \mathrm{M}$ Numerical simulation of photonic crystal based nano-resonators on scanning probe fip for enhanced light confinement [7729-52]

L. Wang, K. Hoshino, X. Zhang, The Univ. of Texas at Austin (United States)

FOOD ANALYSIS USING MICROSCOPY

7729 1P Apple cuticle: the perfect interface [7729-56]

E. Curry, USDA Agricultural Research Service (United States); B. Arey, USDOE (United States)

7729 IR Starch granule formation and protein deposition in wheat (Triticum aestivum L.) starchy endosperm cells is altered by high temperature during grain fill [7729-58]

W. J. Hurkman, D. F. Wood, USDA Agricultural Research Service (United States) 
$77291 \mathrm{U}$ Quality and utilization of food co-products and residues [7729-61]

P. Cooke, New Mexico State Univ. (United States) and USDA Agricultural Research Service (United States); G. Bao, USDA Agricultural Research Service (United States); C. Broderick, Delaware State Univ. (United States); M. Fishman, L. Liu, C. Onwulata, USDA Agricultural Research Service (United States)

$77291 \mathrm{~V} \quad$ Microstructure of Desmanthus illinoensis [7729-62]

D. F. Wood, W. J. Orts, G. M. Glenn, USDA Agricultural Research Service (United States)

\section{BIOLOGICAL}

7729 IW Microscopic examination on cytological changes in Allium cepa and shift in phytoplankton population at different doses of Atrazine [7729-64]

N. Ghosh, K. Finger, S. Usnick, W. J. Rogers, West Texas A\&M Univ. (United States); A. B. Das, Orissa Univ. of Agriculture and Technology (India); D. W. Smith, Univ. of North Texas (United States)

7729 1X Characterization of aeroallergen of Texas panhandle using scanning and fluorescence microscopy [7729-65]

N. Ghosh, M. Whiteside, C. Ridner, Y. Celik, West Texas A\&M Univ. (United States); C. Saadeh, Allergy A.R.T.S. (United States); J. Bennert, Air Oasis LLP (United States)

Author Index 
Downloaded From: https://www.spiedigitallibrary.org/conference-proceedings-of-spie on 26 Apr 2023

Terms of Use: https://www.spiedigitallibrary.org/terms-of-use 


\title{
Conference Committee
}

\author{
Symposium and Conference Chairs
}

Michael T. Postek, National Institute of Standards and Technology (United States)

Dale E. Newbury, National Institute of Standards and Technology (United States)

S. Frank Platek, U.S. Food and Drug Administration (United States)

David C. Joy, The University of Tennessee (United States)

Organizing Committee

Eva M. Campo, Centro Nacional de Microelectrónica (Spain)

David L. Carroll, Wake Forest University (United States)

Lucille A. Giannuzzi, FEl Company (United States)

Brendan J. Griffin, The University of Western Australia (Australia)

R. David Holbrook, National Institute of Standards and Technology (United States)

Dennis A. Margosan, USDA Agricultural Research Service (United States)

Tim K. Maugel, University of Maryland, College Park (United States)

Keana Scott, National Institute of Standards and Technology (United States)

Christopher W. Szakal, National Institute of Standards and Technology (United States)

Michael A. Trimpe, Hamilton County Coroner's Laboratory (United States)

Vladimir A. Ukraintsev, Nanometrology International, Inc. (United States)

Daniel W. van der Weide, University of Wisconsin-Madison (United States)

John S. Villarrubia, National Institute of Standards and Technology (United States)

András E. Vladár, National Institute of Standards and Technology (United States)

David Voci, Carl Zeiss SMT Inc. (United States)

Oliver C. Wells, IBM Corporation (United States)

Delilah F. Wood, USDA Agricultural Research Service (United States) 
Session Chairs

1 Plenary Session

Michael T. Postek, National Institute of Standards and Technology (United States)

Dale E. Newbury, National Institute of Standards and Technology (United States)

S. Frank Platek, U.S. Food and Drug Administration (United States)

2 Desk Top SEM Symposium

Tim K. Maugel, University of Maryland, College Park (United States)

3 Advancements in Particle Beam Microscopy I

Lucille A. Giannuzzi, FEI Company (United States)

David C. Joy, The University of Tennessee (United States)

$4 \quad$ Advancements in Particle Beam Microscopy II

Dale E. Newbury, National Institute of Standards and Technology (United States)

Eva M. Campo, Centro Nacional de Microelectrónica (Spain)

5 Advancements in Scanned Probe Microscopy

Ronald G. Dixson, National Institute of Standards and Technology (United States)

6 Advancements in Particle Beam Microscopy III

Brendan J. Griffin, The University of Western Australia (Australia)

András E. Vladár, National Institute of Standards and Technology (United States)

$7 \quad$ Particle Beam and Scanned Probe Modeling I

John S. Villarrubia, National Institute of Standards and Technology (United States)

András E. Vladár, National Institute of Standards and Technology (United States)

8 Forensic Microscopy: Applications, Analyses and Research

S. Frank Platek, U.S. Food and Drug Administration (United States)

Michael A. Trimpe, Hamilton County Coroner's Laboratory (United States)

9 Advancements in Optical Microscopy I

Eva M. Campo, Centro Nacional de Microelectrónica (Spain)

David L. Carroll, Wake Forest University (United States) 
10 Food Analysis using Microscopy

Delilah F. Wood, USDA Agricultural Research Service (United States)

Dennis A. Margosan, USDA Agricultural Research Service (United States)

11 Biological

Tim K. Maugel, University of Maryland, College Park (United States)

Dennis A. Margosan, USDA Agricultural Research Service (United States) 
Downloaded From: https://www.spiedigitallibrary.org/conference-proceedings-of-spie on 26 Apr 2023

Terms of Use: https://www.spiedigitallibrary.org/terms-of-use 


\section{Introduction}

Welcome to Scanning Microscopy 2010.

The organizers of this meeting and SPIE are pleased to have you attend the second of the SPIE Scanning Microscopy symposia series held in Monterey, California. We are extremely pleased with the technical content of the meeting with over 75 papers submitted this year.

Many of you are aware that spring conferences on scanning microscopy have a history going back over 40 years to 1967 with the "Scanning Electron Microscopy" series started by Dr. Om Johari. Following Dr Johari's retirement, the SCANNING series of conferences, organized by Tony Bourgholtzer of the Foundation for Advances in Medicine and Science (FAMS), continued this tradition. Early in 2007, FAMS decided not to sponsor future SCANNING meetings. Following that announcement, a substantial amount of work was done in the background to find a solution to keep the meeting alive. SPIE agreed to manage the meeting and hence, Scanning Microscopy 2009 and 2010 emerged.

The organizers and SPIE anticipated that the Scanning Microscopy 2010 meeting would bring microscopists from all phases of scanning microscopies (from scanned optics to scanned particle beams) together in a single forum to discuss current research and new advancements in the field. We believe that there are several unique strengths to this meeting such as:

- Forensic applications of SEM

- Scanning ion microscopy (FIB and HIM)

- Quality assurance in SEM and microcharacterization

- Biological environmental/variable pressure SEM: successes and limitations

- Modeling for critical SEM and microanalysis applications

- Scanned probe microscopies

- Scanned optical microscopies

We hope to grow these areas over the next few years. We are excited that the meeting will merge with one of the larger SPIE Symposia in 2011 in Orlando, Florida and following that transition to a more permanent home at the Baltimore Inner Harbor in Maryland.

We invite your ideas for topics, session organizers, speakers for specific presentations, and we welcome your active participation.

Mike T. Postek

Dale E. Newbury

S. Frank Platek David C. Joy 
Downloaded From: https://www.spiedigitallibrary.org/conference-proceedings-of-spie on 26 Apr 2023

Terms of Use: https://www.spiedigitallibrary.org/terms-of-use 